\title{
EFFECT OF COMPOST AND CHEMICAL FERTILIZER ON GROWTH AND CHEMICAL COMPOSITION OF DATE PALM SEEDLING cv. Bertamoda
}

(Received: 3.6.2015)

\author{
By \\ L. M. Abdel-Galeil \\ Central Laboratory of Date palm Research and Development, \\ Agricultural Research Center, Giza, Egypt
}

\begin{abstract}
An investigation was conducted under the green house conditions at the Central Laboratory of date palm Research and development, Giza, Egypt, during 2014 and 2015 seasons to study the effect of different media ; pure sand (s) as a control, Sand+animal manure compost (AMC) at a ratio of (3:1, $\mathrm{v} / \mathrm{v})$,Sand+plant remnant compost (PRC)at ratio of $(3: 1, \mathrm{v} / \mathrm{v})$ and S+AMC+PRC at ratio of $(2: 1: 1, \mathrm{v} / \mathrm{v}$ $/ \mathrm{v}$ ) as well as fertilizer with kristalon (as soil drench) (19:19:19+micronutrients) at the rates of 0, 0.25, 0.5 and $0.75 \mathrm{~g} / \mathrm{l}$, besides their interactions on growth and chemical composition of date palm cv. Bertamoda, grown in $20-\mathrm{cm}$ - diameter plastic pots filled with about $2.5 \mathrm{~kg}$ of one of the previous media.

The results indicated that the medium fortified with plant remanant compost was the best medium for enhancing vegetative growth. This was true for the treatment with kristalon solution (as a soil drench) at the concentration of $0.5 \mathrm{~g} / 1$ which gave the highest increment in vegetative growth rather than the other rates. However, combining medium and fertilization with krisalon exhibited more improvement in growth, especially the combination between planting in S+PRC (3:1) medium and fertilizer with $0.5 \mathrm{~g} / 1$ kristalon solution. This combination gave the best growth in the two seasons. In addition, S+AMC(3:1) medium recorded the highest content of chlorophyll a in both seasons, while $\mathrm{S}+\mathrm{PRC}$ (3:1) medium registered the highest content of clorophyll $\mathrm{b}$. As for carotenoids content, it reached the maximum when the plantlets were cultivated in S+AMC+ PRC (2:1:1) medium. Content of total indoles (ppm) was significantly increased by the 3 used media that gave means closely near together in the two seasons. On the other hand, kristalon solution at $0.5 \mathrm{~g} / 1$ scored the highest means of all the previous constituents in both seasons. Regarding the interactions, results showed that planting in S+ PRC (3:1) medium and fertilizer with $0.5 \mathrm{~g} / \mathrm{l} \mathrm{kristalon(} \mathrm{as} \mathrm{a} \mathrm{soil} \mathrm{drench} \mathrm{)} \mathrm{registered} \mathrm{the} \mathrm{most} \mathrm{high}$ averages in all previous constituents relative to control and all other combinations in both seasons.

It can be recommended to cultivate the one-year-old seedling of date palm cv. Bertamoda in the medium amended with plant remanant compost+ kristalon fertilization solution (as soil drench) at $0.5 \mathrm{~g} / 1$ level to score the best growth and the highest quality under the green house conditions.
\end{abstract}

Kay wards: date palm, Phoenix dactylifera, animal manure compost, plant remnant compost, fertilizer, kristalon.

\section{INTRODUCTION}

Phoenix dactylifera $\mathrm{L}$., Date palm as one of the most important economic crops that belong to the Family. Palmaceae, still the most common and cheap fruit grown in tropical and subtropical areas. The species dactylifera includes many cultivars, some of them give dry fruits such as Malacabe, Sukry, Gargoda, Dhagna and Bertamoda. However, the latter cv. has higher quality than the others ,being taller and has moderate intensity top. The leaflets are tiny, short and are not apart from each other on the frond's midrib.

the use of organic compost, as a cheap substitute for peatmoss, in amending growing medium of small plantlets or seedlings may help them to grow well under nursery conditions because organic matter plays a vital and important role in improving soil physical, chemical and biological fertility. In this concern, Duong (2013) mentioned that municipal soil wastes, straw and manure composts significantly increased aggregate stability and water holding capacity of sandy soil, as well as soil cation 
exchange capacity, soil $\mathrm{N}$ and $\mathrm{P}$ availability, wheat growth and shoot $\mathrm{N}$ and $\mathrm{P}$ contents.On Ficus benjamina cv. Samantha and Schefflera arboricola cv Gold capella, shahin et al. (2013) found that a mixture of sand + peatmoss improved only plant height and the number of leaves /plant, while sand+FYM compost mixture improved all the vegetative and root growth parameters, as well as leaf contet of chorophyll a, b, carotenoids, proline and total carbohydrates. Likewise, EL-sayed et al. (2013) revealed that a growing medium consists of sand+alive meal compost+soybean meal compost+broad bean peels compost at equal parts by volume was the most suitable for the best growth and quality of Euenymus as foliage -pot-plant. Similar observations were also elicited by Abdel-Fattah et al. (2008) on Schefflera, Kassem et al. (2009), on rosemary, Shahin et al., (2012) and Youssef and El-sayad (2013) on Euonymus japonicas cv. Aureus.

Fertilizing small plantlets and seedlings with complete chemical fertilizers usually leads to considerable growth and development responses. This fact was confirmed by Abdel-Galeil (2010a) who found that spraying leaves of date palm cv. Sokkouty plantlets with $20 \mathrm{ml} / 1$ humic acid solution and drenching the soil with $2 \mathrm{ml} / 1$ potssein-N (K-N) significantly improved plant length, the number of leaves, leaf width and leaf content chlorophyll a and b, carotenoids, N, P and $\mathrm{K}$. A similar response was also obtained by Abdel-Galeil (2010a) on date palm cv Malacabe. Moreover, Shahin et al., (2013) declared that plantings 6-month-old transplants of Schefflera and Euonymus in a mixture of sand $+25 \%$ FYM compost plus fertilizing with kristalon at $2 \mathrm{~g} / 1$ pot greatly increased vegetative and root growth and content of photosynthetic pigments, total soluble sugars, $\mathrm{N}, \mathrm{P}$ and $\mathrm{K}$ in the leaves of both plants.

The aim of this study was to examine the effect of medium type, kristalon level and their interactions on growth and chemical composition of date palm cv. Bertmuda seedling under nursery conditions.

\section{MATERIALS AND METHODS}

Two pot experiments were conducted under the green house conditions of the central Lab. of Res. and Date palm, ARC, Giza, Egypt, throughout the two consecutive seasons of 2014 and 2015 to enhance growth and quality of the young seedling of Phoenix dactylifera $\mathrm{L} \mathrm{cv}$. Bertamoda by either chemical fertilizer. or amending the medium with organic compost, or both. One -year seedlings of date palm (produced by tissue culture technic) cv. Bertamoda at about $20-25 \mathrm{~cm}$ long with 3 leaves were planted on March, $10^{\text {th }}$ for each season in $20 \mathrm{~cm}$ diameter plastic pots (one plantlet/pot filled with about $2.5 \mathrm{~kg}$ one of the following media: pure sand (s) as control , S+animal manure compost (AMC)at a ratio of $(3: 1, \mathrm{v} / \mathrm{v}), \mathrm{S}+$ plant remanant compost (PRC) at a ratio of $(3: 1, \mathrm{v} / \mathrm{v})$ and $\mathrm{S}+\mathrm{AMC}+\mathrm{PRC}$ at a ratio of $(2: 1: 1, \mathrm{v} / \mathrm{v} / \mathrm{v})$. Physical and chemical properties of the sand ,as well as the animal and plant composts used in the two seasons were determined (Tables 1 and 2). After 3 weeks from planting (on first of April). kristalon fertilizer solution (19: 19: 19+micronuients ) was added to the seedlings at the rates of $0,0.25$, 0.50 and $0.75 \mathrm{~g} / \mathrm{l}$ as a foliar spray till the solution run -off, six times with one month interval .Futhermore, each level of kristalon was combind with each medium to form 16 combined treatments. All plantlets received the usual agricultural practices recommended for such plantation whenever needed.

Table (1): Some physical and chemical properties of the used sand during the two seasons.

\begin{tabular}{|c|c|c|c|c|c|c|c|c|c|c|c|c|c|c|}
\hline \multirow[b]{2}{*}{ 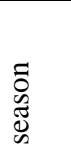 } & \multicolumn{4}{|c|}{ 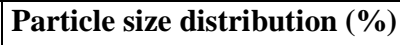 } & \multirow[b]{2}{*}{ S.P } & \multirow{2}{*}{$\begin{array}{c}\text { E.C. } \\
(\mathrm{ds} / \mathbf{m})\end{array}$} & \multirow[b]{2}{*}{ pH } & \multicolumn{4}{|c|}{ Cations (meq/l) } & \multicolumn{3}{|c|}{ Anions (meq/l) } \\
\hline & $\begin{array}{c}\text { Coarse } \\
\text { sand }\end{array}$ & \begin{tabular}{|l|} 
Fine \\
sand
\end{tabular} & Silt & Clay & & & & $\mathbf{C a}^{++}$ & $\mathbf{M g}^{++}$ & $\mathrm{Na}^{+}$ & $\mathbf{K}^{+}$ & $\mathrm{HCO}_{3}^{-}$ & Cl & $\mathrm{SO}_{4}{ }^{-}$ \\
\hline 2013 & 89.03 & $2 . .05$ & 0.40 & $8 . .52$ & 23.01 & 3.56 & 7.9 & 7.50 & 1.63 & 33.6 & 0.50 & 3.20 & 22.0 & 18.03 \\
\hline 2014 & 84.76 & 6.30 & 1.49 & 7.45 & 21.87 & 3.78 & 7.8 & 19.42 & 8.33 & 7.2 & 0.75 & 1.60 & 7.8 & 26.30 \\
\hline
\end{tabular}


Table (2): Some physical and chemical analyses of the used compost in the two seasons.

\begin{tabular}{|c|c|c|c|c|c|c|c|}
\hline & & \multicolumn{2}{|c|}{ Compost } & & & \multicolumn{2}{|c|}{ Compost } \\
\hline Component & Unit & Animal & Plant & Component & Unit & Animal & Plant \\
\hline $\begin{array}{c}\text { Weight of } \\
\mathbf{m}^{3}\end{array}$ & $\mathbf{K g}$ & 840.0 & 543.5 & $\begin{array}{l}\text { Organic } \\
\text { matter }\end{array}$ & $\%$ & 23.18 & 46.63 \\
\hline humidity & $\%$ & 30.0 & 30.0 & $\begin{array}{l}\text { Organic } \\
\text { carbon }\end{array}$ & $\%$ & 13.45 & 27.04 \\
\hline $\operatorname{Ph}(1: 10)$ & - & 7.78 & 8.53 & Ash & $\%$ & 76.82 & 53.37 \\
\hline EC(1:10) & ds I & 2.51 & 4.86 & c/N ratio & - & $16.2 / 1$ & 17.2/1 \\
\hline Total N & $\%$ & 0.83 & 1.33 & Total P & $\%$ & 0.77 & 1.24 \\
\hline NH4 & ppm & 50.0 & 205.0 . & Total K & $\%$ & 0.40 & 0.59 \\
\hline $\mathrm{NO}_{3}$ & ppm & 40.9 & 91.0 & Nematoda & Worm200/g soil & 20 free & n.f. \\
\hline
\end{tabular}

*n.f.=Not found.

*The previous analyses were done on the basis of dry weight except humidity.

The layout of the experiments in both seasons was a complete randomized design in factorial experimental type (Das and Giri, 1986) replicated thrice as each replicate contained 3 plantlets . At the end of each season (October), data were recorded as follows: seedling length (cm) number of leaves / seedling and leaf width (cm).In fresh leaf samples ,photosynthetic pigments (chlorophyll a,b and carotenoids, (mg/l f.w) were measured using the method described by Saric et al.,(1976) and total Indoles (ppm) was assessed according to the method of A.O.A.C. (1980). Data were then tabulated and statistically analyzed using SAS Institute Program (1994), with Duncan's Multiple Range test (Duncan, 1955) to verify the significancy among the means of the different treatments .

\section{RESULTS AND DISCUSSION}

3.1.Effect of growing medium, Kristalon rate and their interaction on

\subsubsection{Vegetative growth characters}

It can be seen from the data averaged in Tables (3, 4 and 5) that plant length $(\mathrm{cm})$, the number at leaves/ plantlet and leaf width $(\mathrm{cm})$ were markedly improved as a result of either amending sand with organic compost or kristalon firtilizer. However, medium fortified with plant remnant compost (PRC) or plantlets fertilized with $0.5 \mathrm{~g} / 1$ kristalon gave the highest means over the control and all other individual treatments in the two seasons. Similarly, all interaction treatments increased the means of various vegetative growth parameters with various significance levels as compared to the control means in both seasons, but the mastery was for planting in $\mathrm{S}+\mathrm{PRC}(3: 1)$ medium plus fertilizer with $0.5 \mathrm{~g} / 1 \mathrm{kristaln}$. This combind treatment recorded the atmost high averages in the first and second seasons.

Stimulation of plant growth due to kristalon application would be reasonable since different nutrients usually activate vital processes which lead to produce essential compounds as carbohydrates, proteins, hormones, enzymes and energy - reserve materials (Mengel and Kirkby, 1979). On the other hand, organic compost also has high manurial value for crop yields

Table (3): Effect of medium, Kristalon and their interactions on plant length ( $\mathrm{cm})$ of Phoenix dactylifera L.cv. Bertamoda plantlets (cm) during 2014 and 2015 seasons.

\begin{tabular}{|c|c|c|c|c|c|c|c|c|c|c|}
\hline \multirow{2}{*}{$\begin{array}{l}\text { Kristalon rate g/l } \\
\text { Medium }\end{array}$} & \multicolumn{5}{|c|}{ First season 2014} & \multicolumn{5}{|c|}{ First season 2015} \\
\hline & 0.0 & 0.25 & 0.50 & 0.75 & Mean & 0.0 & 0.25 & 0.50 & 0.75 & Mean \\
\hline Sand(s) & $\begin{array}{c}20.37 \\
\text { e }\end{array}$ & $\begin{array}{c}22.01 \\
\text { e }\end{array}$ & $\begin{array}{c}23.00 \\
\text { de }\end{array}$ & $\begin{array}{c}24.05 \\
d\end{array}$ & $\begin{array}{c}22.36 \\
\text { c }\end{array}$ & $\begin{array}{c}22.28 \\
d\end{array}$ & $\begin{array}{c}24.10 \\
d\end{array}$ & $\begin{array}{l}25.18 \\
\text { cd }\end{array}$ & $\begin{array}{c}26.98 \\
\text { c }\end{array}$ & $\begin{array}{c}24.64 \\
\text { c }\end{array}$ \\
\hline S+AMC(3:1) & $\begin{array}{c}24.36 \\
d\end{array}$ & $\begin{array}{c}32.67 \\
\text { b }\end{array}$ & $\begin{array}{c}34.65 \\
\text { ab }\end{array}$ & $\begin{array}{c}35.98 \\
\text { ab }\end{array}$ & $\begin{array}{c}31.92 \\
\text { b }\end{array}$ & $\begin{array}{c}26.40 \\
\text { c }\end{array}$ & $\begin{array}{c}33.40 \\
\text { b }\end{array}$ & $\begin{array}{c}33.98 \\
\text { bc }\end{array}$ & $\begin{array}{c}36.29 \\
\text { b }\end{array}$ & $\begin{array}{c}32.52 \\
\text { b }\end{array}$ \\
\hline S+PRC (3:1) & $\begin{array}{c}28.83 \\
\text { c }\end{array}$ & $\begin{array}{c}35.43 \\
\text { ab }\end{array}$ & $\begin{array}{c}40.95 \\
a\end{array}$ & $\begin{array}{c}34.30 \\
\text { ab }\end{array}$ & $\begin{array}{c}34.88 \\
\mathbf{a}\end{array}$ & $\begin{array}{c}\mathbf{3 1 , 5 3} \\
\text { cb }\end{array}$ & $\begin{array}{c}35.81 \\
\text { b }\end{array}$ & $\begin{array}{c}45.12 \\
\text { a }\end{array}$ & $\begin{array}{c}38.61 \\
\text { b }\end{array}$ & $\begin{array}{c}37.77 \\
\mathbf{a}\end{array}$ \\
\hline $\begin{array}{l}\text { S+AM+PRC } \\
(2: 1: 1)\end{array}$ & $\begin{array}{c}26.40 \\
\text { cd }\end{array}$ & $\begin{array}{c}35.29 \\
\text { ab }\end{array}$ & $\begin{array}{c}32.84 \\
\text { b }\end{array}$ & $\begin{array}{c}36.19 \\
\text { ab }\end{array}$ & $\begin{array}{c}32.68 \\
\text { b }\end{array}$ & $\begin{array}{c}28.86 \\
\text { c }\end{array}$ & $\begin{array}{c}35.12 \\
\text { b }\end{array}$ & $\begin{array}{c}35.78 \\
\text { b }\end{array}$ & $\begin{array}{c}36.5 \\
0 b\end{array}$ & $\begin{array}{c}34.07 \\
\text { b }\end{array}$ \\
\hline
\end{tabular}

* AMC=Animal manutre compost,and PRC=plant remnants compost.

* Means within the same row having the same letters are not significantly different according to Duncans multiple Range Test at $5 \%$ levele 
Table (4): Effect of medium, Kristalon and their interactions on the number of leaves/plantlet of Phoenix dactylifear l.cv. Bertmoda plantlets (cm) during 2014 and 2015 seasons.

\begin{tabular}{|c|c|c|c|c|c|c|c|c|c|c|}
\hline \multirow{2}{*}{$\begin{array}{l}\text { Kristalon rate } \\
\text { Medium }\end{array}$} & \multicolumn{5}{|c|}{ First season 2014} & \multicolumn{5}{|c|}{ First season 2015} \\
\hline & 0.0 & 0.25 & 0.50 & 0.75 & Mean & 0.0 & 0.25 & 0.50 & 0.75 & Mean \\
\hline Sand(s) & 3.33d & $3.60 \mathrm{~cd}$ & $3.88 c$ & $4.20 \mathrm{bc}$ & $3.75 b$ & 3.33e & 3.50de & 3.76d & $4.00 \mathrm{~cd}$ & $3.65 b$ \\
\hline S+AMC(3:1) & 3.76 & $4.20 \mathrm{bc}$ & $5.17 \mathbf{a b}$ & 5.13ab & $4.57 a$ & 3.67 & $4.03 \mathrm{~cd}$ & $5.08 b c$ & $5.00 b c$ & $4.45 a$ \\
\hline S+PRC (3:1) & $4.00 \mathrm{~cd}$ & $4.67 b$ & $6.67 a$ & $4.67 b$ & $5.00 a$ & $4.00 \mathrm{~cd}$ & $4.33 c$ & $7.47 \mathrm{a}$ & $5.10 b c$ & $5.23 a$ \\
\hline S+AM+PR $(2: 1: 1)$ & $3.96 \mathrm{~cd}$ & 4.83b & $4.83 b$ & 5.50ab & $4.78 \mathrm{a}$ & 3.84d & $5.10 \mathrm{bc}$ & $5.00 \mathrm{bc}$ & $5.53 b$ & $4.87 a$ \\
\hline Mean & $3.76 b$ & 4.33ab & $5.14 a$ & $4.88 a$ & & $3.71 b$ & $4.24 a b$ & $5.33 a$ & $4.91 a$ & \\
\hline
\end{tabular}

* AMC=Animal manutre compost,and PRC=plant remnants compost.

* Means within the same row having the same letters are not significantly different according to Duncans multiple Range Test at $5 \%$ levele

Table (5): Effect of medium, Kristalon and their interactions on leaf width (cm) of Phoenix dactylifear l.cv. Bertamoda plantlets (cm) during 2014 and 2015 seasons.

\begin{tabular}{|c|c|c|c|c|c|c|c|c|c|c|}
\hline \multirow{2}{*}{$\begin{array}{l}\text { Kristalon rate } \\
\text { Medium g/l }\end{array}$} & \multicolumn{5}{|c|}{ First season 2014} & \multicolumn{5}{|c|}{ First season 2015} \\
\hline & 0.0 & 0.25 & 0.50 & 0.75 & Mean & 0.0 & 0.25 & 0.50 & 0.75 & Mean \\
\hline Sand(s) & 1.71d & $1.85 \mathrm{~cd}$ & $1.99 \mathrm{c}$ & $2.12 \mathrm{cb}$ & $1.92 \mathrm{~b}$ & $1.73 \mathrm{e}$ & $1.89 d$ & $2.00 d$ & $2.20 \mathrm{~cd}$ & $1.96 \mathrm{~b}$ \\
\hline S+AMC(3:1) & $1.86 \mathrm{~cd}$ & $2.69 \mathrm{bc}$ & 3.04ab & 2.90ab & $2.62 a$ & 1.81de & $2.67 \mathrm{bc}$ & 3.07bc & $2.93 \mathrm{bc}$ & $2.62 a$ \\
\hline S+PRC (3:1) & $2.10 \mathrm{cb}$ & $2.81 b$ & $3.93 a$ & $2.30 \mathrm{bc}$ & $2.79 \mathrm{a}$ & $2.13 d c$ & $2.72 b c$ & $4.30 \mathrm{a}$ & $2.35 \mathrm{~cd}$ & $2.88 a$ \\
\hline S+AM+PR (2:1:1) & $2.00 c$ & $2.48 \mathrm{bc}$ & 3.28ab & $2.85 b$ & $2.65 a$ & 2.01d & $2.75 b c$ & $3.40 b$ & $2,81 b c$ & $2.74 a$ \\
\hline Mean & $1.92 b$ & 2.46ab & 3.06a & $2.54 a b$ & & $1.92 c$ & $2.51 b$ & $3.19 \mathrm{a}$ & $2.57 b$ & \\
\hline
\end{tabular}

* AMC=Animal manutre compost,and PRC=plant remnants compost.

* Means within the same row having the same letters are not significantly different according to Duncans multiple Range Test at $5 \%$ levele

(Drechsel and Reck,1998).In this connection ,Handreck and Black (2002) demonstrated that organic compost improved the electrical conductivity (EC),pH and humates in the soil . The well composted organic matter may improve soil structure and texture, increase cation exchange capacity (CEC) and fertility (Singh, 1999). Besides, rising the water holding capacity of the growing medium and consequently water uptake by plants which leads finally to activate vital processes to produce more constituents necessary for more growth and high quality (Gonzalez and cooperband, 2003).

These results are consistent with these of Abdel-Galeil (2010b) on date palm cvs. Malacabe and sakkoty, Shahin et al. (2012) and Youssef and EL-sayed (2013) on Euonymus japouicus cv. Aureus and shahin et al . (2013) on Ficus benjamina cv Samantha and Scheffera arboricola cv. Gold capella.

\subsubsection{Chemical composition}

According to the data presented in Table (6), it is clear that S+AMC (3:1) medium gave the highest content of chlorophyll a ( $\mathrm{mg} / \mathrm{g}$ f.w)in both seasons, while S+PRC (3:1) medium gave the highest content of chlorophyll b. As for carotenoid content, it was true for $\mathrm{S}+\mathrm{AMC}+\mathrm{PRC}(2: 1: 1)$ medium which recorded the utmost high content in the two seasons. However, the total indole content (ppm) was significantly increased by the 3 used media as they gave means closely near each other with non-significant differences among them. On the other hand kristalon at the rate of $0.5 \mathrm{~g} / 1$ gave the highest content of all constituents mentioned above compared to the other levels in both seasons. In the matter of interaction treatments, combining between planting in S+PRC(3:1) medium and firtilizer with $0.5 \mathrm{~g} / 1$ kristalon caused the highest increment in all previously mentioned constitnents relative to all other combinations in the two seasons.

The aforestated results may indicate the role of both organic matter compost and kristalon in supplying the plantlets with nutrients necessary for accelerating biosynthesis processes which increase, as a result, the content of active constituents in plantlet tissues. In this regard, Gonzalez and Cooperband (2003) observed that duck manure compost increased soil content of $\mathrm{C}, \mathrm{N}, \mathrm{P}$ and $\mathrm{Cu}$, as well as available $\mathrm{P}, \mathrm{S}, \mathrm{Ca}$, 
Table (6): Effect of medium ,Kristalon and their interaction on some chemical constituents of Phoenix dactylifear l.cv. Bertamoda plantlets (cm) during 2014 and 2015 seasons.

\begin{tabular}{|c|c|c|c|c|c|c|c|c|c|c|}
\hline \multirow{2}{*}{$\begin{array}{l}\text { Kristalon rate } \mathrm{g} / \mathrm{l} \\
\text { Medium }\end{array}$} & \multicolumn{5}{|c|}{ First season 2014} & \multicolumn{5}{|c|}{ First season 2015} \\
\hline & o.o & 0.25 & 0.50 & 0.75 & Mean & 0.0 & 0.25 & 0.50 & 0.75 & Mean \\
\hline \multicolumn{11}{|c|}{ Chlorophyll a(mg g f.w.) } \\
\hline Sand(s) & $0.201 i$ & $0.241 h$ & $0.296 f$ & $0.273 g$ & $0.253 \mathrm{c}$ & $.215 f$ & $0.256 \mathrm{e}$ & 0.310de & $0.281 \mathrm{e}$ & $0.266 \mathrm{c}$ \\
\hline S+AMC(3:1) & 0.230hi & $0.445 \mathrm{e}$ & $0.601 b$ & $0.534 c$ & 0.453a & $0.258 \mathrm{e}$ & $0.535 b c$ & $0.605 b$ & $0.445 d$ & $0.461 \mathrm{a}$ \\
\hline S+PRC (3:1) & $0.250 \mathrm{~g}$ & $0.250 \mathrm{gh}$ & 0.78a & $0.267 \mathrm{~g}$ & 0.387b & $0.265 \mathrm{e}$ & $0.270 \mathrm{e}$ & $0.782 a$ & $0.226 f$ & 0.386b \\
\hline S+AM+PR (2:1:1) & $0.245 h$ & $0.439 \mathrm{e}$ & $0.456 d$ & $0.293 f$ & $0.358 b$ & $0.261 \mathrm{e}$ & $0.443 d$ & $0.461 \mathrm{~cd}$ & $0.287 \mathrm{ed}$ & $0.363 \mathrm{~b}$ \\
\hline Mean & $0.232 c$ & $0.344 b$ & 0.534a & $0.342 b$ & & $0.250 \mathrm{c}$ & $0.376 b$ & $0.540 \mathrm{a}$ & $0.310 b$ & \\
\hline \multicolumn{11}{|c|}{ Chlorophyll b (mg g f.w.) } \\
\hline Sand(s) & 0.170i & 0.197h & 0.229gh & 0.232gh & $0.207 b$ & $0.172 \mathrm{~g}$ & $0.193 g$ & o.231f & $0.226 f$ & $0.206 b$ \\
\hline S+AMC(3:1) & 0.185h & $0.337 \mathrm{e}$ & $\mathbf{0 . 5 0 3 b}$ & $0.246 \mathrm{~g}$ & 0.318ab & $0.188 \mathrm{~g}$ & 0.341de & 0.507b & o.750ef & 0.322ab \\
\hline S+PRC (3:1) & $0.202 \mathrm{~h}$ & $0.372 \mathrm{~d}$ & $0.589 a$ & $0.287 f$ & $0.363 a$ & $0.210 f$ & $0.373 d$ & $0.592 a$ & $0.300 \mathrm{e}$ & $0.369 \mathrm{a}$ \\
\hline S+AM+PR (2:1:1) & 0.193h & $0.293 f$ & $0.434 c$ & $0.368 d$ & 0.322ab & 0,200gf & $0.301 \mathrm{e}$ & $0.435 c$ & 0.376d & 0.328ab \\
\hline Mean & $0.188 c$ & $0.300 b$ & $0.439 a$ & $0.283 b$ & & $0.193 c$ & $0.302 b$ & $0.441 \mathrm{a}$ & $0.288 b$ & \\
\hline \multicolumn{11}{|c|}{ Chlorophyll c (mg g f.w.) } \\
\hline Sand(s) & $0.112 k$ & $\mathbf{0 . 1 3 5 j}$ & 0.178i & $0.167 i$ & 0.148b & $0.112 i$ & $0.140 \mathrm{~g}$ & 0.171f & 0.193e & $0.154 c$ \\
\hline S+AMC(3:1) & 0.123jk & $0.268 f$ & $0.315 c$ & $0.205 h$ & $0.228 a$ & 0.125gh & $0.272 \mathrm{~cd}$ & $0.314 b c$ & $0.203 \mathrm{e}$ & $0.229 b$ \\
\hline S+PRC (3:1) & 0.136j & $0.281 \mathrm{e}$ & $0.360 \mathrm{a}$ & $0.216 \mathrm{~h}$ & 0.248a & $0.140 \mathrm{~g}$ & $0.280 \mathrm{~cd}$ & $0.362 a$ & 0.120gh & $0.226 b$ \\
\hline S+AM+PR (2:1:1) & 0.131j & $0.245 \mathrm{~g}$ & $0.322 b$ & 0.304d & $0.251 a$ & $0.140 \mathrm{~g}$ & 0.244d & 0.323b & $0.304 c$ & $0.253 a$ \\
\hline Mean & $0.126 c$ & $0.232 b$ & $0.299 a$ & $0.223 b$ & & $0.129 \mathrm{c}$ & $0.234 b$ & $0.293 a$ & $0.205 b$ & \\
\hline
\end{tabular}

* AMC=Animal manutre compost, and PRC=plant remnants compost.

* Meano within the same row having the same letters are not significantly different according to Duncans multiple Range Test at $5 \%$ levele

Table (7): Effect of medium, Kristalon and their interaction on constituents of Phoenix dactylifear l.cv. Bertamoda plantlets (cm) during 2014 and 2015 seasons

\begin{tabular}{|c|c|c|c|c|c|c|c|c|c|c|}
\hline $\begin{array}{c}\text { Kristalon } \\
\text { rate } \mathrm{g} / \mathrm{l} \\
\text { Medium } \\
\end{array}$ & 0.0 & 0.25 & 0.50 & 0.75 & Mean & 0.0 & 0.25 & 0.50 & 0.75 & Mean \\
\hline sand(s) & $1.56 \mathrm{k}$ & $1.87 \mathrm{i}$ & 2.33h & $1.98 \mathrm{i}$ & $1.94 b$ & $1.53 \mathrm{i}$ & $1.81 \mathrm{~h}$ & $2,48 f$ & $2.03 g$ & $1.69 \mathrm{~b}$ \\
\hline S+AMC(3:1 & $1.70 \mathrm{j}$ & 4.55d & $4.69 \mathrm{c}$ & $4.90 \mathrm{~b}$ & $3.96 a$ & $1.67 \mathrm{hi}$ & 4.51c & $4.68 \mathrm{bc}$ & $4.88 \mathrm{~b}$ & 3.94a \\
\hline S+PRC (3:1) & $1.85 \mathrm{i}$ & $4.76 \mathrm{c}$ & $5.14 a$ & $2.66 \mathrm{~g}$ & 3.60a & $1.82 \mathrm{~h}$ & $4.75 b$ & $5.25 \mathrm{a}$ & $2.65 \mathrm{e}$ & 3.62a \\
\hline \multirow[t]{2}{*}{$\begin{array}{c}\text { S+AM+PR } \\
(2: 1: 1)\end{array}$} & $1.63 \mathrm{j}$ & $3.94 e$ & $4.45 c$ & $3.84 f$ & $3.54 a$ & $1.60 \mathrm{i}$ & 3.93d & 4.75b & 3.77de & 3.51a \\
\hline & $1.69 \mathrm{c}$ & 3.76b & 4.23a & 3.34b & & $1.66 \mathrm{c}$ & $3.75 b$ & 4.29a & 3.44b & \\
\hline
\end{tabular}

$\mathrm{Mg}, \mathrm{K}$ and $\mathrm{Zn}$. On the same line, the same was true in the findings postulated by Abdel-Galeil (2010a) on date palm cvs. Malacabe and Sakkoty, Shahin et al. (2012) on Schfflera and Euonymus and Duong (2013) on wheat.

From the foregoing,it can be concluded that binding between cultivation in a mixture of sand+plant remnant compost $(3: 1)$ and fertilizing with kristalon solution at $0.5 \mathrm{~g} / \mathrm{l}$ as a soil derunch is the best way to lump the beneficial effects of both growth and quality of date palm cv. Bertamoda plantlets under nursery conditions. 


\section{REFERENCES}

Abdel-Fattah G. H., Rezk-Alla B. B. and ElFanly A. S. (2008). Effect of some organic additives to sand on growth and chemical composition of Schefflera actimaphylla plant. Ann. Agric. sci., Moshtohor, 46 (4): 477-482.

Abdel-Galeil L. M. (2010a). Response of date palm plantlets cv Malacabe to some fertilization treatments. J. Biol. chem. Environ. Sci., 5(1):43-55.

Abdel-Galeil L. M. (2010b). Improving the growth of date plam cv.sakkoty plantlets by some fertilization treatments. J. Biol. chem. Environ Sci.,5 (1):109-122.

A.O.A.C. (1980). Official Methods of Analysis of the Association of official Agricultural chemists. $15^{\text {th }}$ Ed., Arlington, Virginia, USA, 22201:877-878.

Das M. N. and Giri N. C. (1986). Design and Analysis of Experimentes, $2^{\text {nd }}$ Ed., Mohinder Singh Sejwal (pub.) for Wiley Eastern Ltd., New Delhi India, 488pp.

Drechsel P. and Reck B. (1998). Compost shrubprunings and other organic manures for small holder farming systems in southern Rwanda. Agroforest systems, 39 (1):1-12.

Duncan D.B.(1955). Multipe range and multiple F-tests. J. Biometrics, 11:1-42

Duong T.T. (2013). Compost effects on soil properties and plant growth. Ph.D. thesis, School of Agric., Food and wine, Adelaide Univ., Australia.

El-sayed B. A., El-Fouly A. S. and Shahin S.M. (2013). Response of Euonymus japonicas Thunb.cv. Aureus to some growing media. J. Biol. chem. Environ. Sci., 8(3):61-71

Handreck K. and Black N. (2002). Growing media for ornamental plants and Turf. $3^{\text {rd }}$ Ed., Univ. of New South Wales Press Ltd., Sydney, Australia, 542PP.
Gonzalez R. F. and Cooprband L. R. (2003). Compost effects on soil chemical properties and field nursery production .J. Environ. Hort., 21(1): 38-44.

Kassem H., Abier H. R. A., Mehasen R. and Mousa F. (2009)Effect of salinity and compost level on growth, chemical composition and oil production of rosemay (Rosmarinus officinalis L.) plant, Egypt. j. Hort., 36(1):219-230.

Mengel K. and Kirkby E. A. (1979). Principals of plant Nutrition, $2^{E d}$, International Potash Inst., Bern, Switzerland, 593 pp.

Saric M., Kastrori R., Curic R., Cupina T. and Geric I. (1976). Chlorophyll Determination, 215 pp. Univ. U Noven Sadu Parktikum is Fiziologize Biljaka, Beogard, Haucna, Anjiga.

SAS Institute (1994). SAS/STAT User's Guides Statistics. Vers. 6.04, $4^{\text {th }}$ Ed., SAS Institute Inc., Cary, N.C., USA.

Shahin S.M., El-Tayeb H. F. and El-sayed B. A. (2012). Effect of some media and fertilization treatments on growth and quality of some foliage pot plant. J. Biol. chem Environ. Sci., 7(1): 93-112.

Shahin S. M., El-Fouly S. A. and Abdel-Sattar M.M. (2013). Response of Ficus benjamina L. cv. Samantha and Schefflera arboicala_Endl. cv. Gold copella plants cultivated in two different growing media to salinity of irrigation water. J. Biol. chem. Environ. Sci., 8 (2) : 201-218.

Singh R.D.(1999). Status of IPNS in V.P. hills. Fertilizer New, 44 (8): 39-41.

Youssef H. M. A. and El-sayed B. A. (2013). Studying the effect of compost and some natural extracts on growth and quality of Euonymus Japonicus Thunb. cv. Aureus plants. J.Biol. chem Environ. Sci.,8 (1): $33-42$. 
تأثير الكومبوست والتسميد الكيماوى على النمو والمحتوى الكيماوى لثتلات نخيل البلح صنف برتمودا

لبنى محمد عبد الجليل

المعمل المركزى لابحاث وتطوير نخيل البلح ـ مركز البحوث الزراعية ـ الجيزة- مصر

أجريت هذه التجربة فى الصوبة الزراعية التابعه للمعطل المركزى لأبحاث وتطوير نخيل البلح- مركز البحوث

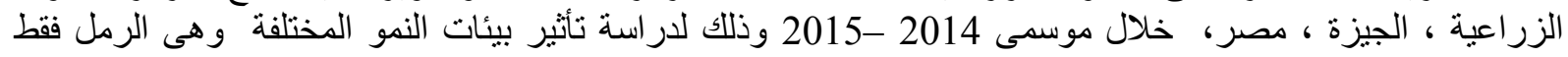

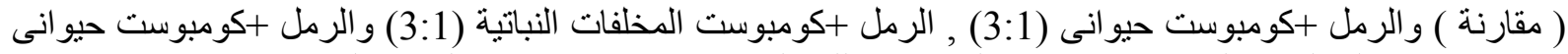

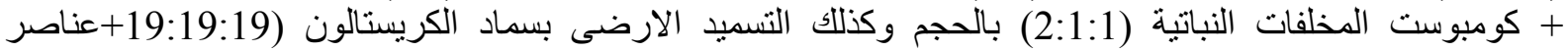

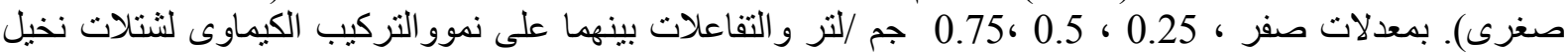

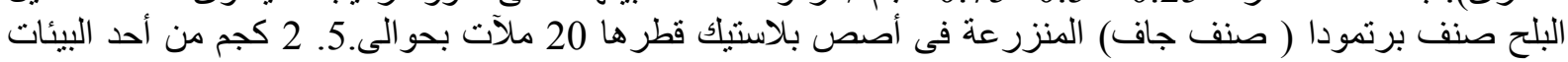

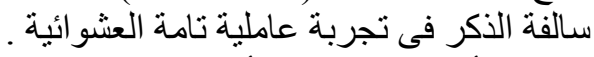

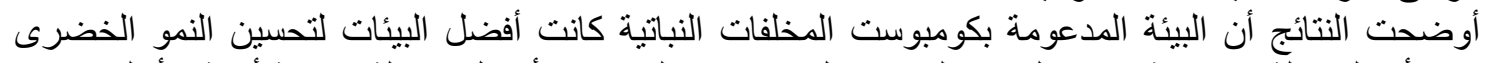

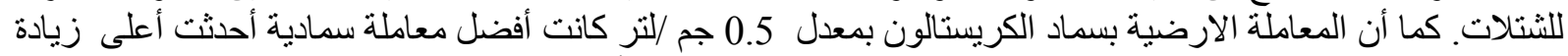

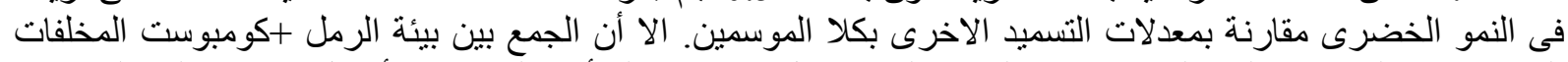

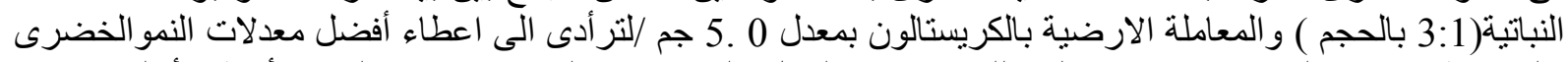

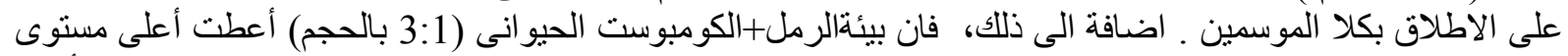

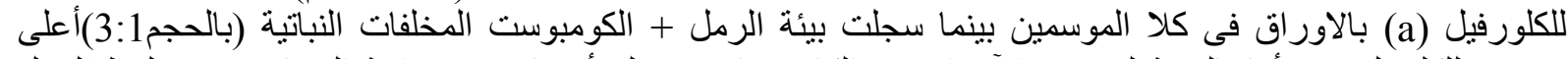

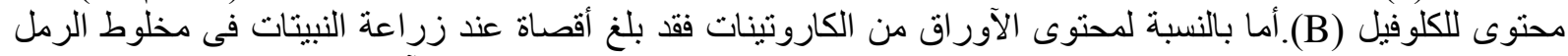

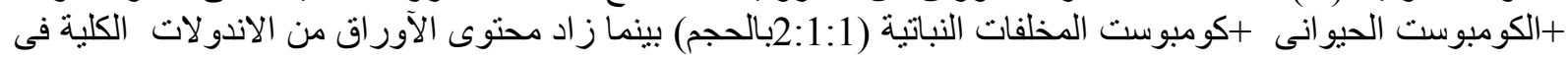

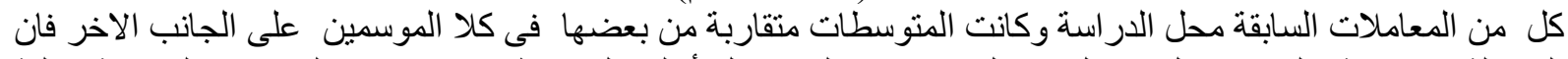

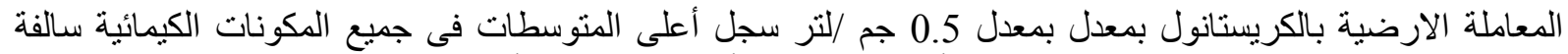

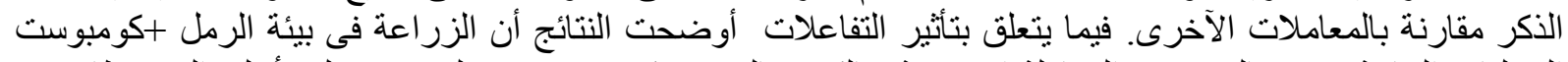

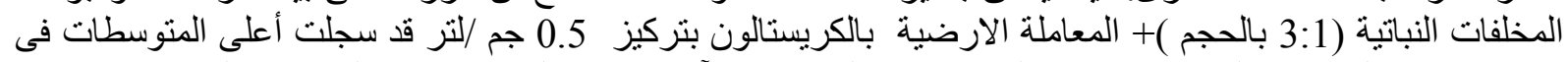

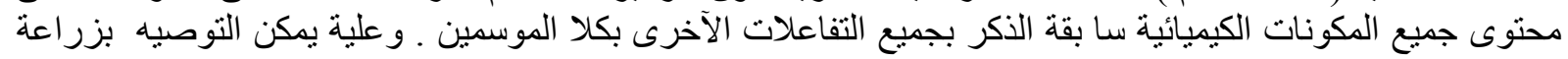

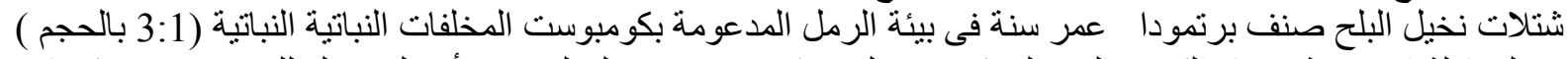

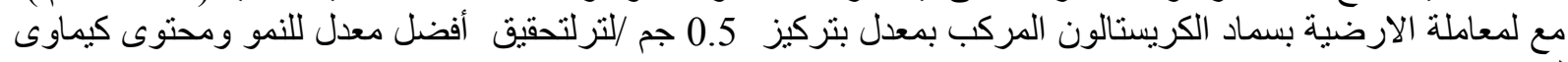
للاور اق . لمعاملة 